9-2003

\title{
The Economics of International Monies
}

Gerald P. Dwyer Jr.

James R. Lothian

Fordham University

Follow this and additional works at: https://fordham.bepress.com/crif_working_papers

Part of the Finance and Financial Management Commons

\section{Recommended Citation}

Dwyer Jr., Gerald P. and Lothian, James R., "The Economics of International Monies" (2003). CRIF Working Paper series. 10. https://fordham.bepress.com/crif_working_papers/10

This Article is brought to you for free and open access by the Frank J. Petrilli Center for Research in International Finance at DigitalResearch@Fordham. It has been accepted for inclusion in CRIF Working Paper series by an authorized administrator of

DigitalResearch@Fordham. For more information, please contact considine@fordham.edu. 


\title{
The Economics of International Monies
}

\author{
Gerald P. Dwyer Jr. \\ and \\ James R. Lothian*
}

September 2003

\begin{abstract}
The purpose of this paper is to examine the history of international monies and the theory related to their adoption and use. We summarize the history of international monies, beginning with a discussion of the gold solidus introduced in the fourth century by the Emperor Constantine, continuing with the currencies of the Italian city states and ending with the currencies that have functioned as international monies from the early modern period to the present. We identify four key characteristics of these currencies: high unitary value; relatively low inflation rates for long periods; issuance by major economic and trading powers; and spontaneous, as opposed to planned, adoption internationally. We conclude with a theoretical discussion of these common characteristics that explains much of this history (JEL E42, F33, N10 ).
\end{abstract}




\section{Introduction}

In January 2004, the Euro will have celebrated its second birthday as a circulating medium within most but not all of the EU countries and its fourth birthday as a unit of account. So far the change from the individual domestic currencies in the 12 countries involved has been seamless.

Denmark, Sweden and the United Kingdom remain outside the system, however, and show little inclination at the moment to alter their status. In Denmark and, much more recently, Sweden, the only two countries to hold a referendum on becoming part of the eurozone, voters overwhelmingly rejected the proposal. In the United Kingdom, with public opinion polls pointing to a similar result, the referendum has been put of indefinitely. At the same time, the value of the Euro relative to both the U.S. dollar and sterling has been subject to sizable movements, depreciating substantially at the outset, then bouncing back and finally as of this writing moving back down a bit again.

Despite these negative developments, most observers regard its future as positive, and certainly much better than appeared to be the case a decade ago. At the time, devaluations and widened currency bands shook the Exchange Rate Mechanism (ERM), and skepticism with regard to the implementation of a single European currency was the rule among both economists and traders and other financial professionals. A key reason for the shift in opinion was the change that took place in the monetary and inflation environments in the countries involved, in particular the greater convergence to the low and stable rates of inflation of Germany and the countries closely linked to it. 
What is the likelihood of this success continuing? Is the euro likely to become a dominant, or the dominant, international money in the world, as some of its supporters hope?

In this paper we attempt to shed light on both issues. We begin by examining the long history of international monies and common currencies. With the lessons derived from this historical analysis as backdrop, we go on to discuss the theory surrounding these issues.

Our historical survey begins with a discussion of the Byzantine gold solidus or bezant introduced by the Emperor Constantine in the fourth century and used as a world currency for the next seven centuries. We continue with a review of medieval monetary history and the international currencies of the Italian city states. ${ }^{1}$ We then turn to a discussion of the various international monies that have existed from the early modern period to the present and the currency unions that were formed in Europe and elsewhere in the more recent part of this period.

In discussing the theory, we focus on a set of factors that history suggests affect the establishment of common currencies and, more important, their longevities. Recent theoretical analyses based on trade and financial markets have indeterminacies that cannot be resolved by those theories. The earlier analyses of Carl Menger (1892) and a century later Friedrich A. Hayek (1978a) provide some important clues with regard to the choice of the actual international money. In both Menger's and Hayek's analyses, the key distinction is between institutions -- in this instance monetary institutions -- that are the result of human action but not human design and institutions that are planned and orchestrated from on high. We conclude with a discussion of their thinking and its intellectual roots. 


\section{Historical Overview}

\subsection{The Early Middle Ages}

International monies, monies that circulate for use in transactions across national boundaries, begin with the silver drachma first coined in ancient Athens in the fifth century B.C. (Chown, 1994). ${ }^{2}$ Judged on the basis of the hoards that have been uncovered, not just within the Mediterranean region but throughout Europe and well into Asia, the coinage of Rome - first the gold aureus and later, after the currency reforms of Augustus, the silver denarius - became the drachma's successor. ${ }^{3}$ Beginning with Nero (A.D. 54-68) and continuing into the early fourth century, currency debasement and inflation became the rule. An unsurprising effect of this continual depreciation was a decline in the acceptability of the Roman coinage outside the narrower confines of the Roman empire. The denarius, which had its specie content reduced, ceased entirely to function as money internationally. The aureus, which kept its fineness in terms of specie but was issued as a lighter coin, became more commodity than money, being valued by weight rather than at face value.

After earlier attempts at reform failed, the Emperor Constantine introduced a new currency, the solidus. Called the nomisma by the Greeks and the bezant by Western Europeans, the solidus continued to be minted in Byzantium until that city fell to the crusaders in 1203, and for a while thereafter was still minted in Nicea, the new seat of the then much diminished Byzantine Empire.

The solidus was a relatively heavy, full-bodied gold coin meant for use in large transactions. It soon became an international currency. A contemporary observer, the Greek monk Cosmas Indicopleustes, writing during the reign of the Emperor Justinian I (A.D. 527- 
565), reported that the solidus was "accepted everywhere from end to end of the earth." It is, he went on to say, "admired by all men in all kingdoms, because no kingdom has a currency that can be compared to it." The economic historian and medievalist R.S. Lopez (1951) in reviewing the solidus' history used the term "Dollar of the Middle Ages" to describe it. Based on the hoards of coins that subsequent research has uncovered, he traced a very large sphere of influence from England to India (an area in which he claimed (p. 211) it was accepted "as an instrument of payment as good as gold itself.")

The solidus contained the equivalent of 4.5 grams of pure gold. The British gold sovereign and the ten-dollar gold U.S. Eagle by way of comparison contained roughly 8.0 and 8.8 grams, respectively. Valued at current market prices the gold in the solidus would be worth roughly $\$ 42$ and the gold in the eagle and the sovereign $\$ 73$ and $\$ 68$ respectively. Numismatic evidence suggests, moreover, that the solidus' gold content varied little from the fourth century through the mid-tenth century.

The result was an international money with an historically unparalleled life span. The solidus did not, however, enjoy a monopoly over this full period. From the end of the seventh century, it shared its position with the dinar, an almost identical coin minted in various parts of the Moslem world. Introduced in the last decade of the seventh century by Abd el Malek, the fifth caliph (A.D. 685-705) of the Syrian Umayyad dynasty, the dinar like the solidus kept a stable metallic content for centuries.

The fall from grace of the solidus and dinar began at roughly the same time and for very much the same reasons. Fiscal strains led to increased money creation which for commodity monies meant debasement in one or both of two forms -- a decrease in the weight of the coins or 
alteration of their specie content, their fineness. From the standpoint of the usefulness of the currency in trade and hence confidence in it, the first was the less harmful of the two. Coins could be valued by weight as would indeed be done for substantially worn coins even in the absence of debasement.

For the solidus, debasement came in the form of reduced weight starting in the late tenth century under the Emperors Nicephorus Phocas (963-969) and John Tzimiskes (969-976) and continuing into the eleventh. The cause, as so often has been the case, was the need to finance high levels of government expenditures. ${ }^{5}$ The death knell for the solidus' status as an international currency was sounded in the late eleventh century when the alloy was altered. Nevertheless, a solidus of close to the old weight was still minted (along with inferior coins) in the early thirteenth century in Nicea following the fall of Constantinople to the Crusaders in 1203. The dinar also began to be debased in the late tenth century. The cause, again here too, appears to have been largely fiscal.

\subsection{The Thirteenth Century Commercial Revolution and the European Return to Gold}

Although the reach of the solidus did extend well into Northern Europe, the Mediterranean region was where it was used most extensively. Northern Europe, and Western Europe in general, had no counterpart to the solidus and was otherwise less of a monetary economy than either the Byzantine Empire or the Moslem nations.

In the thirteenth century that situation changed. The thirteenth century was extraordinary in a number of ways. By all accounts it was a time of great leaming and considerable scholarly interchange. ${ }^{6}$ It was also the start of a European commercial revolution, the chief manifestation of which was substantially increased trade, not only within Europe itself but between Europe and 
the rest of the then known world. It was, in addition, a time of considerable financial innovation, including the return to gold coinage in Western Europe.

International trade was centered around the fairs that were held regularly throughout Europe, the fairs of Champagne being the most important. These fairs also were foreignexchange centers. Initially the money changers at the fairs confined their activities to manual exchange, the changing of one type of coin for another. Then as bills of exchange increasingly came into use, the money changers, as did some merchants themselves - whence the term "merchant banker" - increased their roles and became intermediaries in this market.

The reintroduction of a Western European gold coinage took place in 1252 with the striking of two full-bodied gold coins in Northern Italy - the genoin of Genoa and then a few months later the fiorina (or florin) of Florence. For the next century and a half these two coins, the florin particularly, were the world currencies. In the fifteenth century, however, their place was taken by the ducato of Venice. All three coins circulated side by side with coins of two other sorts - token coins used in small transactions and silver coins used in somewhat larger transactions.

Gresham's Law did not come into play in any of the three instances because exchange rates among the various coinages remained flexible. Judged by the data that exist for this period there was a surprisingly active market in foreign exchange. Exchange-rate data, in fact, indicate why the two coins, the florin and the genoin, proved attractive and became international currencies. We can see this in Table 1 which lists exchange rate quotes at fifty-year intervals for a variety of currencies relative to the florin. 
Two features of the data are immediately apparent. The first is the noticeable depreciation of all currencies relative to the florin indicated by the upward trend in all of the exchange rates. The second point is the substantial difference across countries in the pace at which the exchange-rate depreciation occurred. The English pound sterling, for example, showed relatively little movement, a drop in value of 0.2 per cent per year over these two and a half centuries; the Castilian marivedi, in contrast, registered a decline of 2.0 per cent per year over the 200 years for which data on it are available.

A major cause of these movements was the series of debasements that took place in all of the European countries throughout this era. A second influence was the discovery and subsequent mining of silver in several countries of Europe during the fifteenth century. The influence of currency debasement can be seen quite in Table 2 which lists the percentage changes over the full period 1252-1500 of a subset of the florin exchange rates together with estimates of the degree of debasement. The two are quite clearly related. The simple correlation and the rank correlation between the two are .94 .

The depreciation of these currencies does not seem to have been matched by increases in the various countries' price levels. The likely reason is that increases in money supplies were themselves matched at least to some degree by increases in real output and in desired quantities of money demanded.

These currencies, therefore, also served as units of account and as a base for the credit instruments - the bills of exchange - that beginning in the thirteenth century evolved into the principal form of international settlement. ${ }^{7}$ The principal purpose of these bills of exchange was to eliminate the need for specie to be shipped each time goods were bought and sold. The 
mechanism was simple and evidently also quite effective, since the bill of exchange remained the major form in which foreign exchange transactions were affected throughout most of the nineteenth cen tury. ${ }^{8}$ Discountable bills still survive in modified form today, with payment now commonly being ensured by letters of credit.

\subsection{Common Characteristics of Early International Monies}

Cipolla (1967) reviews monetary developments in both the early and later medieval period and points to three common characteristics of the various international monies. The first is high unitary value. We have already discussed this in connection with the solidus. It was also true of the dinar and three Italian coins. The dinar contained approximately 4.25 grams of gold and the three Italian coins contained approximately 3.5 grams. Valuing these again at today's price of gold of roughly $\$ 290$ per troy ounce, this works out to prices of roughly $\$ 40$ and $\$ 32$ respectively. In the United States today by way of comparison, the largest bill commonly used in cash transactions is a twenty-dollar bill.

The second characteristic that the medieval monies shared during their respective heydays was intrinsic stability. They all kept the same weight and fineness during these periods though their values in terms of goods and services did change over time. Correspondingly, in each instance after debasement set in, the currency eventually ceased to serve as an international money.

The third characteristic is that the various currencies were all issued by strong economic powers that were active in international trade. Since we will go on to consider international 
monies in today's context of fiat monies, it is useful to consider how well these apply to that world.

The second of these requisite characteristics, intrinsic stability, would seem to be the most relevant for the success of fiat monies also. In current terminology, it provided a nominal anchor. It applies with at least equal force to fiat monies as to commodity monies since the real value of fiat money can be easily affected by the issuer, something not as directly manipulable by issuers of commodity monies.

The rationale for the third observed characteristic, a large economy with a substantial presence in world trade, is somewhat harder to pin down. Recently developed search-theoretic models of money, which we review below, suggest however that such scale effects do indeed matter. An alternative view is that a strong trade-oriented economy is simply an indicator of brand-name capital. Like sterling during the period in which Britain was the world's major power and the dollar today, such currencies could be viewed as subject to less risk of political upheaval. In either case, this generalization again applies with equal or greater force to fiat monies.

High unitary value seems to be another matter completely. It is certainly not much of a restriction on fiat monies, because fiat monies weigh relatively little and it is cheap to change the units to whatever value makes them useful in international transactions. Cipolla, however, suggests that it might in fact be a mark of prestige. Lopez (1951) in his discussion of early medieval monies makes somewhat the same observations. He says (p. 214-215 ):

Clearly, then, the bezant was more than a lump of gold. It was a symbol and a faith, the messenger of the divine emperor to his people and the ambassador of the chosen people to other nations of the world. We cannot make fair appraisal of the monetary policies of 
the empire in strict economic terms since moral and psychological values also were involved and since these values by affecting the internal stability and international prestige of the state had, in their turn, a bearing on economic conditions.

We think it is also useful to make explicit a fourth characteristic of these various world currencies: All of them were simply adopted. None of these intemational monies arose due to anyone's initial intention to create a new intemational money. Rather, in each instance their roles as international monies evolved due to their becoming generally acceptable to others over time. They thus achieved their status without any laws being passed, any official monetary conferences being held, or any foreign ministers issuing joint communiques. They became world monies, to use Hayek's (1978b) terminology in the article of that name, as "the result of human action and not of human design."

\section{International Monies and Common Currencies from the Seventeenth Century on}

As the sixteenth century wore on, the center of international trade shifted from the Mediterranean region and the Italian city states to the northwest corner of Europe, first to Antwerp and then rather abruptly near the close of that century to the Dutch Republic. In the century that followed, the Dutch economy experienced rapid growth. The United Provinces as a result became the world leader in shipping and in trade as well as in international finance. Not surprisingly, the Dutch currency became the key currency in international transfers. It remained so, moreover, for most of the seventeenth and eighteenth centuries (see Dehing and 't Hart, 1997). Its strong suit, in addition to the preeminent Dutch economic and financial position, was its intrinsic stability. 
The rise of the guilder was an evolutionary process. At the end of the sixteenth century, close to 800 different foreign coins were accepted in the Dutch Republic as money, and by 1810 the number had increased to nearly 1000 ( Dehing and 't Hart, 1997). Out of this bewildering array, the guilder emerged as the unit of account and the primary transactions currency. These two functions were, however, split between two versions of the currency. The guilder banco, the deposit entries on the books of the Bank of Amsterdam, became the unit of account. The circulating silver guilder came to serve as the medium of exchange. The two guilders - banco and coin - were closely, but not rigidly, linked. In 1638 the Amsterdam magistrates set a par value for the bank money in terms of the circulating medium, with the guilder banco at a slight premium. This premium, the agio, remained generally small and quite stable. Over the period, 1638 to 1775 the agio averaged 4.1 per cent, implying an average internal rate of exchange between the two of 104.1 in guilder coinage per 100 guilder banco. The standard deviation of the agio over this period was only 1.1 per cent. ${ }^{9}$ The debasements that had been characteristic of the guilder until roughly 1630 , therefore, clearly had become a thing of the past. As John McCusker (1978, p. 42) summarized the situation, "This unchanging metallic content ... during the seventeenth and eighteenth centuries made Dutch money - with sterling - one of the soundest, most stable currencies in the world."

During the course of the seventeenth century, Dutch economic growth slowed appreciably and English growth began to accelerate (Israel, 1995). Near the end of that century, England started to develop into a financial power. The initial event here was the chartering of the Bank of England in 1694. Rapid development of English commercial banking followed. In the latter half of the eighteenth century, the number of London banks increased close to threefold and the 
number of banks outside London - the country banks - grew even faster, from a dozen or so in 1750 , to 334 in 1797, to double that number in 1810 (Ashton, 1955, pp. 179-183). During this period, the London Stock Exchange also was formed and an active market in foreign exchange developed.

By the last quarter of the eighteenth century, England had replaced the Dutch Republic as the world's leading trading nation and London had replaced Amsterdam as its chief financial center (Jonker, 1997). Throughout, sterling remained a relatively stable currency and, although this stability was temporarily interrupted in the decade or two surrounding the Napoleonic Wars, it was reestablished soon afterward and maintained until the start of the First World War.

Sterling as a result, became the new international currency, benefitting not only from its inherent stability but also and, we suspect, more importantly from the new British primacy in international trade and finance. ${ }^{10}$

The United States became the world's largest econ omy in the late nineteenth cent ury, with U.S. real GDP surpassing U.K. real GDP in the last third of that century. British financial and monetary dominance, however, continued until the start of the First World War. With the outbreak of war came substantial gold flows from Europe, including the United Kingdom, to the United States. New York, which had already become a major financial center, benefitted and London lost. After the Armistice in November of 1918, the world tried to get back to normal. Many of the belligerent countries returned to gold in the early 1920s. The United Kingdom only did so in 1925, after first experiencing half a decade of wrenching deflation. Sterling retained some of its status as an international money and reserve currency for a time, but the position of 
the U.S. dollar in both regards strengthened. Then the Great Depression and W orld W ar II intervened and financial and trade links between countries, as much else, got disrupted.

At the Bretton Woods Conference in 1944 the U.S. dollar was designated the official reserve currency of the fixed-exchange-rate system designed at that meeting. After the war ended, the dollar not only took on this role but also became an international money and the currency used in domestic transactions in various countries. A good flavor for what went on during this period and its resemblance to times past can be had from Cipolla's discussion (1967, p.13) in his monograph on Medieval monies in which, like Lopez (1951), he likens the solidus to the dollar.

These pieces of paper [i.e. dollars], I knew, were more generally acceptable than any European currency. In any part of Europe there could be no difficulty in finding people who would take them as money. I could spend then everywhere, asking for everything. They were, they are, the international currency par excellence.

Fixed exchange rates among the world's currencies broke down in 1971 under the pressures unleashed by inflationary monetary policy in the United States (Darby, Lothian, et al., 1982: Bordo, 1993). At the time it was widely believed that the move to floating exchange rates that followed would lead to a substantial diminution in the dollar's role. This proved wrong on several counts. For one thing, official holdings of dollars as reserve assets remained high and in the decades that followed greatly increased. So too did private demands for dollars, particularly once the United States got inflation under control and as other countries' inflation scenarios worsened. 


\subsection{Further Empirical Generalizations}

Later experience also is consistent with the Cipolla's emphasis on the importance of country size and prominence in trade as well as stability of value. What also appear to be important are financial development and financial sophistication. All three of the later international currencies - the guilder, sterling and the dollar - were issued by countries with dominant positions in international finance and relatively unfettered markets. Cohen (1971, 1998) discusses this last characteristic under the headings of "exchange convenience" and “capital certainty.” George S. Tavlas (1998) makes a similar point. He states that:

"the issuing country should possess financial markets that are substantially free of controls, broad (that is, containing a wide variety of financial instruments), and deep (that is, having well-developed secondary markets)."

Tavlas argues additionally that the issuing country must be politically stable and militarily powerful. This was certainly true of the three countries issuing these later international monies. It was also the case for the issuers of the earlier monies.

\section{Common Currencies and Currency Unions}

What then can be said about common currencies and currency unions? What does history tell us about this question, which it could be argued is particularly germane to the Euro and its prospects?

In answering this question and discussing experience with common currencies, it is useful to distinguish between two sets of arrangements - common currencies within some unified 
political whole and common currencies shared by otherwise independent countries. We discuss the second of these first. The two classic examples here are the Latin Monetary Union and the Scandinavian Monetary Union, both of which came into being in the second half of the nineteenth century. A third is Great Britain and Ireland. We then go on to discuss three unilateral arrangements - Germany, Italy, and the United States.

\subsection{Multinational Currency Unions}

The Latin Monetary Union, a currency union linking France, Belgium, Italy and Switzerland got its start at French initiative at the Paris Conference of 1865. All four countries were on the bimetallic standard and the initial impetus for the union came about following a fall in the price of gold and the resultant strains this imposed in bimetallic countries. As Chown (1994, pp. 85, 86) citing earlier commentators points out, whether these were of great enough importance to alter the system is debatable. ${ }^{11}$ In any event, change it did and the result was a gold standard in which each country coined both gold and silver, each country's coins were accepted in the other three countries and the silver coins made up a subsidiary coinage. For a time the union worked well enough. But then the relative prices of the two metals changed initiating a new round of pressures and France and Italy for fiscal reasons began issuing paper currencies. These difficulties, though a source of strain, did not cause the demise of the system. The Latin Monetary Union failed after the substantial increase in money supplies that accompanied World War I.

The Scandinavian Monetary Union, a gold-standard currency union linking Denmark, Norway and Sweden, was formed in 1873, less than a decade after the formation of the Latin Monetary Union. All three countries had been on the silver standard and had histories of 
interchangeable notes and coins. According to Bordo and Jonung (2000, pp. 26, 27) four factors were responsible for the currency union. One was the desire to switch to gold since Britain and Germany, who were both on gold, were major trading partners of the countries involved. The other three were the eradication of existing arbitrage opportunities among the currencies that had led to inflows of Danish and Norwegian coins to Sweden; a desire to switch to decimal units, which was a secondary feature of the new united currency, the krona; and the then burgeoning sentiment of "Scandinavism." Like its southern European counterpart, Scandinavian Monetary Union did not, however, survive World War I.. The krona was made inconvertible in 1914, all three countries inflated and the Danes and Norwegians did so at a greater rate than the Swedes. The initial result was the change in official parities that was effected in 1915; the end result was a complete breakdown of the system.

A third multinational monetary union (though not always considered as such) is the currency union that existed between Great Britain and Ireland with one interruption from 1737 until 1979. Ireland at the time of the English invasions in the seventeenth century had not seen the spread of the money economy. Thereafter English gold and silver coins began to circulate in Ireland but at premia relative to their values in England. In 1701 the disparity between the two was made official and the rate between the two was set at 1s.1d. Irish per 1s. sterling. In 1737 this was changed to $22 \mathrm{~s} .9 \mathrm{~d}$. Irish per sterling guinea (i.e. $21 \mathrm{~s}$.), implying a premium on sterling of $81 / 3$ per cent. This premium continued to hold until 1797 when both countries suspended specie payment. Within a year, the two currencies had depreciated relative to gold and the Irish pound had depreciated relative to sterling. In 1823, both returned to gold with par between the two currencies set at one to one and sterling made legal tender in Ireland which in the interim had 
been annexed to English by an act of the English Parliament. The two currencies remained united even after the 1922 formation of the Irish Free State and the post-WWII founding of the Irish Republic until 1979. At that point the Irish punt and the pound sterling were decoupled and Ireland became part of the ERM. The impetus for the move was twofold - to escape the still high UK inflation and to forge closer links with the countries of the European continent.

\subsection{National Currency Unions}

The United States, Germany and Italy are all examples of countries that at one time had regional currencies and that eventually adopted a common currency. In the United States the move to a common currency came with the signing of the US Constitution on 1789. It gave Congress the sole power to coin money. As Bordo and Jonung point out, however, this only went part way since the individual states chartered banks and these banks issued bank notes. Nevertheless it was only during the Civil War period (1861-65) that the currency union broke down, and that breakdown ended with the war.

For Germany and Italy, as in the case of the United States, common currencies came following political unification. In Germany this happened with the establishment of the Reichsbank in 1875 . In Italy, it came close to a decade and half earlier. There political unification was completed in 1861. A year later a unified coinage was introduced. In Italy, the unified currency survived continuously thereafter. In Germany, however, it was interrupted following the post-WWII division of the country and the establishment of the Soviet-backed regime in East Germany (1945-90). 


\subsection{Conclusions with regard to Currency Unions}

The principal conclusion that comes out of the analysis of the nineteenth- and twentiethcentury experience with currency unions is that political union, if not actually a sine qua non, matters greatly, affecting both the establishment of currency unions and their continued existence. In each instance in which currency union broke down, political union had either broken down itself or had never been established. In both sets of circumstances, after shocks of one sort or another intruded, the system crumbled. Sometimes these shocks were monetary; in more than a few instances they were real, brought about various wars. ${ }^{12}$

\section{Theoretical Considerations}

On one level, it is trivial to say that international fiat monies have arisen due to their being accepted as international monies. A domestic fiat money arises due to its being generally acceptable in transactions, and there is no obvious reason that an intemational fiat money should be any different. In fact, the level of indeterminacy is more obvious for international fiat money. It may seem obvious that Thai people would prefer to use the Thai government's fiat money. It is much less obvious whether a Thai will pick American, Brazilian, British or Swiss money when using non-Thai money.

If legal restrictions are ignored, there is no particular reason to expect people in Thailand to bear substantial costs to use money issued by the Thai government rather than by some other government. While people may be willing to bear some costs to use domestically produced money due to national pride or other nonpecuniary considerations, there is no reason to think that they will bear substantial costs. Programs to encourage people to buy domestically seldom, if 
ever, succeed. People buy the clothing that has the highest value to them personally, even if it is produced by foreigners. There is an important difference, though, between money and other domestic goods such as clothes. The money that is useful depends on what money is used by others, whereas a pair of shoes will be equally useful whether everyone else wears domestic or foreign shoes. There is a coordination problem that must be solved for choosing money, a problem that is largely irrelevant for clothes. It would be easy, though, to overemphasize the greater importance of coordination for money compared to other goods. Driving a foreign car is more useful if some other people drive one too because repair facilities will be nonexistent otherwise. The producer of the good, whether of car or money, has an incentive to assist users. When all this is said, the choice of an international fiat money still has a substantial indeterminacy not generally present elsewhere. Why do people in the British Virgin Islands use United States dollars rather than United Kingdom pounds sterling? Arguably, the proximity of the United States Virgin Islands which use dollars is a big influence. This begs the question, though, because the United States Virgin Islands could use pounds sterling. It might seem that legal-tender laws, which require that a particular money be acceptable in payment, resolve the question to some extent. Everything else the same, if one money is legal tender and the other is not, the one that is legal tender seems likely to be the money used. Alternative monies rarely are perfect substitutes though.

\subsection{More Stable Money}

One reason that alternative monies are not perfect substitutes is that likely inflation rates for different monies can be quite different. Expected inflation and variable unexpected inflation impose costs on holders of the money, and both expected inflation and variable unexpected 
inflation can generate revenue for an issuer of money. Expected inflation is costly to a holder of money because the real value of the money depreciates while it is being held. More variable unexpected inflation can generate costs because relative prices are less predictable and the risk of engaging in various activities is higher. Expected inflation generates revenue directly to the issuer because printing more money creates higher inflation. More variable unexpected inflation can generate more revenue because the unexpected higher inflation can be generated by printing more money, and the unexpected lower inflation raises the real quantity of cash balances demanded, which can be provided by printing more money (Aurenheimer 1974). The literature on time consistency and related issues, starting with Barro and Gordon (1983), shows that alternating periods of high inflation fueled by printing money and low inflation with money printed to provide the increased demand for money are difficult to sustain as an equilibrium. Even so, the incentive to produce such an outcome means that it can affect even a rational expectations equilibrium. Moreover, this incentive can affect the transition to a rational expectations equilibrium when agents are learning the preferences of the money issuer. In models with learning, governments can acquire a reputation for producing low, predictable inflation, but they also can acquire reputations for producing high inflation (Sargent 1999). Even if the choice of local currency is affected by legal tender laws, the choice of an international money is not affected directly by such laws. Hence, a money's reputation is all the more important for what money will be used as international money. As a result, it is not surprising that Cipolla (1967) places substantial weight on the stability of the money for determining what will be used as international money. It surely is important. 


\subsection{International Trade}

Why might it also matter how much international trade is done by a country, as Cipolla (1967) suggests? At first glance, it is not obvious why this should matter at all. Even though Switzerland is a small country, people might well find Swiss francs to be the most useful currency and the importance of inflation would suggest that as a real possibility. Even if a highinflation country engages in a lot of trade, why would anyone want to use its money as an international medium of exchange?

Reflection on the functions of money, though, suggests that the quantity of trade will matter, and recent theoretical research provides support for this notion. The functions of money directly related to trade include its being a unit of account and a medium of exchange. Considering costs of changing prices - menu costs - suggests that a reputation for low inflation is likely to be the important attribute for which currency is used as a unit of account because it affects the frequency of price changes. On the other hand, if the money used for a trade is different from the money used for posting the price, there is little obvious gain from posting the price in a stable currency since the actual transaction price in the unstable money has to be computed from the posted price in the stable money and the current exchange rate between the stable money and the unstable money. Menu costs interpreted narrowly would have to be very important in order to justify posting prices in a money different from the one used in the transaction. In domestic economies, prices commonly are posted in currencies other than the one used in trades only in the case of extraordinary inflations. Hence, it seems likely that the money used as an international unit of account will tend to be the dominant international medium of exchange. 
Search-theoretic models of money show why the amount of international trade will matter for the choice of the money used as a medium of exchange. The indeterminacy of the choice of a particular fiat money as an international medium of exchange is very clear in the context of the search theories of money introduced by Kiyotaki and Wright (1989) and elaborated in a series of papers culminating in Trejos and Wright (1995). These search-theoretic models are particularly well suited to examining the general issue of international money because they do not impose the use of any particular money, or of money at all. Cash-in-advance models presuppose that a money must be used and models with money in the utility function presuppose that a money is useful. Search theories of money allow for the endogenous choice of a money to solve the general problem of finding a double coincidence of wants.

The generality of allowing for an endogenous choice of money is bought at the price of the theoretical analysis being highly stylized. The choice of a particular international money is examined in Matsuyama, Kiyotaki and Matsui (1993) and Trejos and Wright (1996). In these search-theoretic models of international money, countries are defined effectively by the probability that people will meet, and people can trade when they meet. People within a country have a probability of meeting another person from their country and a separate probability of meeting a foreigner. The probability of meeting a person within the country is assumed to be higher than the probability of meeting a foreigner. Trade is effected by an exchange of a money for a good when both sides find such a trade advantageous. This trade can be an exchange for either domestic or for foreign money. ${ }^{13}$ Matsuyama, Kiyotaki and Matsui (1993) show that the likelihood of using a foreign money is higher in equilibrium if the other country is larger and if the probability of meeting a foreigner is higher. 
In short, a country that is larger and engages in more international trade is more likely to have its money used as an international money. This conclusion is derived holding constant other characteristics of the money, including the stability of the money.

These models have multiple steady-state equilibria for any sizes of economies and degrees of integration, even holding constant the reputation of the money for stability. In short, they tell us that many things are possible. Search-theoretic models of money are not completely vacuous though; they do show why more intemational trade makes it more likely that a country's money will be used as an international money.

\subsection{International Finance}

Financial markets have become increasingly important over time and one might expect that financial markets are likely to affect the choice of international money. For example, foreign central banks hold dollar reserves, but they do not hold dollar bills. Instead, they hold United States government securities. The costs of buying and selling United States government securities affect foreigners' willingness to hold dollar-denominated assets.

Portes and Rey (1998) and Rey (2001) show that transactions costs on securities markets are likely to play an important role in the choice of an international money. The amount of trading in foreign exchange markets affects the cost of trading monies for each other and can affect the choice of what Portes and Rey call a vehicle currency - a currency that is used as an intermediate currency when trading one currency for another (Rey 2001, p. 443.) As Rey shows in a formal model, direct trade of Chilean pesos for Thai baht can be more costly than indirect trade of Chilean pesos for a vehicle currency with a subsequent trade of the vehicle currency for Thai baht. The cost of trade, which Rey identifies with the bid-ask spread, depends on volume; 
higher volume markets have lower bid-ask spreads for reasons well known since Demsetz's (1968) analysis.

Portes and Rey (1998) generalize this explicit theoretical analysis of foreign exchange trading to securities markets. The vehicle currency may be held for some finite time and an interest-bearing security will be held when the cost of using the securities market is lower than the interest that can be received. As a result, the costs of trading on securities markets in a country will affect its use as an international money.

Just as in search-theoretic models of international money, Portes and Rey's analysis of vehicle currencies reaches a similar conclusion concerning equilibrium: There are multiple equilibria and the theory itself provides no guide to which equilibrium will be chosen.

\subsection{What Determines the Actual Equilibrium?}

While it is possible at this level of generality just to say that there are multiple equilibria and leave it at that, it is neither desirable nor necessary to do so. Additional factors will determine the actual equilibrium observed. As Menger (1892, p. 250) summarizes the point, even the use of money domestically is

the spontaneous outcome, the unpremeditated resultant, of particular, individual efforts of the members of a society, who have little by little worked their way [to a particular solution]. Actions that, in themselves, do not have any obvious implications for what money or monies will be international money can affect the actual money used.

Writing in a more general context, Hayek makes much the same point (1973, pp. 8-9). In doing so, he contrasts two views. The first, which he regards as largely false, holds that "human institutions will serve human purposes only if they have been deliberately designed for this end." The other, which he views as much closer to the truth, is that institutions that work and that 
channel individual actions effectively are almost always institutions that came about as a result of evolution, "a process in which practices which had first been adopted for other reasons, or even purely accidentally, were preserved because they enabled the group in which they had arisen to prevail over others."

Underlying Hayek's analysis is the same information-based argument that he had earlier made with regard to the market economy (Hayek, 1945). As he himself pointed out, this is not at all a new argument. It is basically the same reasoning that Bruno Leoni (1961) and a number of earlier English jurists applied to the common law. ${ }^{14}$ In somewhat different form it can also be found in the writings of the sixteenth century scholastic moral philosophers and theologians associated with the University of Salamanca and much earlier still in the reflections on moral philosophy and natural law by St. Thomas Aquinas. ${ }^{15}$

One of the most straightforward explanations that we have found about why evolutionary development is preferable is in Edmund Burke's Reflections on the Revolution in France (1986), in which he writes:

If I might venture to appeal to what is so much out of fashion in Paris, I mean to experience, I should tell you that in my course I have known and, according to my measure, have co-operated with great men; and I have never yet seen any plan which has not been mended by the observation of those who were much inferior in understanding to the person who took the lead in the business. By a slow but well-sustained progress the effect of each step is watched; the good or ill success of the first gives light to us in the second; and so, from light to light, we are conducted with safety through the whole series. We see that the parts of the system do not clash. The evils latent in the most promising contrivances are provided for as they arise. One advantage is as little as possible sacrificed to another. We compensate, we reconcile, we balance. We are enabled to unite into a consistent whole the various anomalies and contending principles that are found in the minds and affairs of men. From hence arises, not an excellence in simplicity, but one far superior, an excellence in composition. Where the great interests of mankind are concerned through a long succession of generations, that 
succession ought to be admitted into some share in the councils which are so deeply to affect them. If justice requires this, the work itself requires the aid of more minds than one age can furnish.

Burke's reference to Paris, it could be argued, has more than historical significance. As Chown (2003, p. 222) points out, there is still a wide gulf separating British and French views on the functioning of the body politic, and the role of the state.

\section{Conclusions}

The history of international monies from the fourth to the twentieth centuries provides a useful set of stylized facts. There has been a sequence of intemational monies, each gaining ascendancy for several centuries and at times much more, but then eventually being replaced by another. The only exception to this generalization is the dollar, which is the current international money and, therefore, has not been replaced. These currencies have had four key characteristics: they have had high unitary value; they have had relatively low inflation rates for long time periods; they have been issued by major economic and trading powers; and they became international monies by human action rather than by design. More recent international monies indicate that efficient financial markets go hand in hand with a country being the issuer of an international money.

To varying degrees, economic theory explains the potential importance of these factors. The size of a country matters because it affects the likelihood that someone in another country will trade with someone from that country and therefore the usefulness of a common money in trading. Efficient financial markets matter because they lower the cost of holding a vehicle currency. On the other hand, economic theory still does not deliver a necessary reason that people 
from two different countries will pick a particular money - es pecially a particular fiat money. The cost of trading particular currencies will affect this choice, but the cost of trading will be affected by the volume of others' exchange. In short, there is a dramatic coordination problem. Historically, this coordination problem has been solved partly by the relative values of metals, and therefore the usefulness of their denominations, and partly by the historical evolution of the choice of money. With fiat monies, the historical evolution of the use of any particular money assumes prime importance because the size of a monetary unit is easy to change. Relative inflation rates affect the cost of holding different monies and therefore will affect the actual money used.

What does this analysis suggest for the euro? The euro area is large enough in terms of trade to be a serious competitor to the dollar as an international money. Indeed, some European countries that are not part of the European System of Central Banks (ESCBs) have adopted the euro. Whether the euro will replace the dollar in other geographic areas depends on two factors. The cost of holding euros relative to the dollar - largely determined by the relative inflation rate for the euro compared to the dollar - will be very important. A more important factor for the euro than for other international monies, though, is the permanence of the euro itself. The EU is an international organization and, while the single new money - the euro - has been created in part to raise the cost of leaving the ESCBs, it is not at all impossible for a country to do so. In this respect, the euro is more nearly analogous to currency unions than to an international money, and currency unions' history has been one of formation and disintegration, as our brief overview and the analyses of other scholars indicate (Bordo and Jonung, 2000; Chown, 2003). If the 
European area evolves more nearly into a common government, then such disintegration becomes impossible short of civil war.

In sum, the future of the euro is still in doubt. One can, for instance, envision a scenario in which coss-country differences in cyclical behavior created sufficiently severe strains on the system that one or more countries decided to abandon the euro and go it alone monetarily. ${ }^{16}$ If something of that sort does not happen, and the euro persists for, say, fifty or a hundred years, it could indeed supplant the dollar as international money provided that euro zone inflation remains low relative to that of the United States. 


\section{References}

Aquinas, St. Thomas (1981) Summa theologica; translated by Fathers of the English Dominican Province. Allen, Tex: Christian Classics, 1981.

Ashton, T.S. (1955) An Economic History of England: The $18^{\text {th }}$ Century, New York: Barnes and Noble.

Aurenheimer, Leonardo (1974) "The Honest Government's Guide to the Revenue from Money Creation,” Journal of Political Economy 82, May-June: 598-606.

Barro, Robert J. and Gordon, David B. (1983) "A Positive Theory of Monetary Policy in a Natural Rate Model," Journal of Political Economy 91, August: 589-610.

Bordo, Michael D. ( 1993) "The Bretton Woods International Monetary System: A Historical Overview, " in Michael D. Bordo and Barry Eichengreen (eds.) A Retrospective on the Bretton Woods System, Chicago: University of Chicago Press for the NBER, 3-104.

Bordo, Michael D. and Jonung, Lars (2000) Lessons for EMU from the History of Monetary Unions, London: Institute of Economic Affairs.

Burke, Edmund. (1986) Reflections on the Revolution in France, London, Penguin Books, 1986 [first published 1790].

Chafuen, Alejandro A. (1986) Christians for Freedom Late-Scholastic Economics. San Francisco: Ignatius Press.

Chown, John F. (1994) The History of Money from AD 800, London: Routledge.

Chown, John F. (2003) A History of Monetary Unions, London: Routledge.

Cipolla, C. M. (1963) Currency depreciation in medieval Europe. Economic History Review, 15, 413-422.

Cipolla, C.M. (1967) Money, Prices, and Civilization in the Mediterranean World, Fifth to Seventeenth Century, New York: Gordian Press.

Cohen, Benjamin J. (1971) The Future of Sterling as an International Currency. London, Macmillan; New York, St. Martin's Press.

Cohen, Benjamin J. (1998) The Geography of Money. Ithaca, N.Y.: Cornell University Press.

Darby, Michael, Lothian, James R., and Arthur E. Gandolfi, Alan C. Stockman and Anna J. 
Schwartz. (1983) The International Transmission of Inflation. Chicago: University of Chicago Press for the NBER.

Dehing, Pit and 't Hart, Marjolein (1997) "Linking the Fortunes: Currency and Banking, 15501800," in Marjolein 't Hart, Joost Jonker, and Jan Luiten van Zanden (eds.) A financial history of the Netherlands, Cambridge and New York: Cambridge University Press, 3763.

Demsetz, Harold.(1968) “The Cost of Transacting." Quarterly Journal of Economics 82, February: 33-53.

De Roover, Raymond (1974) Business, Banking, and Economic Thought in Late Medieval and Early Modern Europe (Julius Kirshner, ed.) Chicago : University of Chicago Press, 1974.

Dwyer, Gerald P., Jr., and James R. Lothian. 2003. "International Money and Common Currencies in Historical Perspective," in a volume forthcoming from Oxford University Press. Oxford: Oxford University Press.

Einzig, Paul (1970). The History of Foreign Exchange. 2nd ed. London: Macmillan.

Gilson, Etienne (1991) The Spirit of Medieval Philosophy. Notre Dame, Ind.: University of Notre Dame Press.

Hale, Sir Matthew (1971) The history of the common law of England. Edited and with an introduction by Charles M. Gray. Chicago: University of Chicago Press.

Hayek, Friedrich A. (1945) "The Use of Knowledge in Society," American Economic Review, 1. 35, No. 4., September: 519-530.

Hayek, Friedrich A. (1973) Law, legislation and liberty, Vol.1, Rules and order. Chicago: University of Chicago Press.

Hayek, Friedrich A. (1978) The Denationalization of Money: An Analysis of the Theory and Practice of Current Currencies. London: Institute of Economic Affairs (1978a).

Hayek, Friedrich A. (1978) “The Result of Human Action not of Human Design,” in Friedrich A. Hayek (ed.) Studies in Philosophy, Politics, Economics, and the History of Ideas.

Chicago: University of Chicago Press (1978b).

Hudson, John (1996) The formation of the English common law : law and society in England from the Norman Conquest to Magna Carta, London and New York: Longman, 1996.

Israel, Jonathan I. (1995) The Dutch Republic: Its Rise, Greatness and Fall, 1477-1806. Oxford: 
Clarendon Press.

Jonker, Joost, "The Alternative Road to Modernity: Banking and Currency, 1814-1914," in Marjolein 't Hart, Joost Jonker, and Jan Luiten van Zanden(eds.) A Financial History of the Netherlands, Cambridge and New York: Cambridge University Press, 1997, 94-123.

Kiyotaki, Nobuhiro, and Wright, Randall (1989) “On Money As A Medium of Exchange.” Journal of Political Economy 97, August: 927-54.

Leoni, Bruno (1961) Freedom and the law. Princeton, N.J., Van Nostrand.

Lopez, Robert S. (1951) “The Dollar of the Middle Ages,” Journal of Economic History 11, Summer: 209-234.

Lothian, James R. (2002) "The internationalization of money and finance and the globalization of financial markets," Journal of International Money and Finance, 21, November: 699-724

Lothian, James R. (2003) "Exchange Rates.” Ox ford Encyclopedia of Economic History. Oxford: Oxford University Press.

Matsuyama, Kiminori; Kiyotaki, Nobuhiro and Matsui, Akihiko (1993) "Toward A Theory of International Currency." Review of Economic Studies 60, April: 283-307.

McCusker, John J. ( 1978) Money and Exchange in Europe and America, 1600-1775. A Handbook. Chapel Hill, N.C.: University of North Carolina Press for the Institute of Early American History and Culture.

Menger, C. (1892) “On the Origins of Money,” Economic Journal 2, June: 239-55.

Neal, Larry (1990) The Rise of Financial Capitalism, Cambridge: Cambridge University Press.

Portes, Richard and Hélène Rey. (1998) "Euro vs Dollar: Will the Euro Replace the Dollar as the World Currency?" Economic Policy: A European Forum 26, (April) 307-22.

Rey, Hélène. (2001) "International Trade and Currency Exchange.” Review of Economic Studies 68 (April), 443-64.

Rolnick, Arthur J., François R. Velde and Warren E. Weber (1996) "The Debasement Puzzle: An Essay in Medieval Monetary History." Journal of Economic History 56, December: 789808.

Sargent, Thomas J. (1999) The Conquest of American Inflation. Princeton: Princeton University Press. 
Schumpeter, Joseph A. (1954) History of Economic Analysis. New York: Oxford University Press.

Selgin, George (1994) "On Ensuring the Acceptability of a New Fiat Money." Journal of Money, Credit and Banking 26, November: 808-26.

Spufford, Peter. (1998) Money and its Use in Medieval Europe. Cambridge and New York: Cambridge University Press..

Spufford, Peter (1984) "Le rôle de la monnaie dans le révolution commericiale du xiiie siècle," in Etudes d'histoire monétaire / textes réunis par John Day, Lille: Presses universitaires de Lille.

Sussman, Nathan(1993) "Debasements, Royal Revenues, and Inflation in France During the Hundred Years' War, 1415-1422.” Journal of Economic History 53, March: 44-70.

Tavlas, George S. (1998) "The International Use of Currencies: The U.S. Dollar and the Euro," Finance \& Development 35, June: 46-49. Available at http://www.imf.org/external/pubs/ft/fandd/1998/06/tavlas.htm

Trejos, Alberto, and Wright, Randall (1996) "Search-Theoretic Models of International Currency.” Federal Reserve Bank of St. Louis Review 78, May/June1996: 117-132.

Trejos, Alberto, and Wright, Randall (1995) "Search, Bargaining, Money, and Prices." Journal of Political Economy 103, February: 118-41.

VanDrunen, David (2002) "Aquinas and Hayek on the Limits of Law: A Convergence of Ethical Traditions," Journal of Markets and Morality, 5, Number 2, Fall: 315-337.

Vaubel Roland (2003) "The future of the euro, a public choice perspective" in Forest H. Capie and Geoffrey E. Wood (eds.) Monetary Unions: Theory, history, public choice. London: Routledge, 146-181

Velde, François R., Warren E. Weber and Randall Wright. (1999) "A Model of Commodity Money, with Applications to Gresham's Law and the Debasement Puzzle." Review of Economic Dynamics 2, January: 291-323. 
Table 1. Indices of exchange rates relative to the Florentine florin.

\begin{tabular}{lrrrrrr}
\hline & 1252 & 1300 & 1350 & 1400 & 1450 & 1500 \\
\hline Austria & 90 & 100 & 141 & 225 & 333 & 495 \\
Castile & & 100 & 431 & 1137.9 & 2586.2 & 6465.5 \\
Cologne & 37.5 & 100 & 336.3 & 630 & 915 & 1680 \\
England & 80 & 100 & 100 & 96 & 121.3 & 146.7 \\
Flanders & & 100 & 128.3 & 255.2 & 373.3 & 609.5 \\
Florence & 42 & 100 & 135 & 163 & 172 & 194 \\
France & 80 & 100 & 250 & 220 & 312.5 & 387.5 \\
Genoa & 47 & 100 & 163 & 146 & 256 & 373 \\
Milan & 58 & 100 & 186 & 186 & 377 & 475 \\
Rome & 58.8 & 100 & 138.2 & 214.7 & 290.2 & 382.4 \\
Venice & 75 & 100 & 100 & 145.3 & 181.3 & 193.8 \\
\hline
\end{tabular}

Source: Lothian (2003 forthcoming), with additional data from Spufford $(1986,1988)$. 
Table 1. Exchange rates changes and debasement

\begin{tabular}{lcc}
\hline & Debasement & Exchange rate change \\
\hline England & 63.3 & 60.6 \\
France & 129.1 & 157.8 \\
Genoa & 168.4 & 207 \\
Milan & 205.1 & 211 \\
Venice & 120.4 & 94.9 \\
Florence & 176.4 & 195 \\
\hline
\end{tabular}

Source: Cippola (1963) and Table 1 above.

Note: Figures are in per cent terms. 


\section{Notes}

* Vice President, Research Department, Federal Reserve Bank of Atlanta, 1000 Peachtree Street N.E., Atlanta, Georgia 30309, USA, tel. 1404 498-7095, email: Gerald.P.Dwyer@atl.frb.org; and Distinguished Professor of Finance, Schools of Business, Fordham University, 113 West $60^{\text {th }}$ Street, New York, NY 10023, USA, tel.: 1212636 6147; email: lothian@fordham.edu. We thank Sven Arndt, Benjamin J. Cohen and George von Furstenberg for comments on earlier drafts of this paper and Linda Mundy for editorial assistance. This paper is a revised version of Dwyer and Lothian (2003). The views expressed here are the authors' and not necessarily those of the Federal Reserve Bank of Atlanta or the Federal Reserve System.

1. On these issues see Cipolla (1967) and (Lothian, 2003).

2. Certain parts of the historical discussion draw heavily on our earlier paper (Dwyer and Lothian, forthcoming).

3. This discussion of Roman currency draws on Einzig's (1962) monograph on exchange-rate history. As Cohen (1998) points out, there was a substantial overlap period after Rome's ascendancy in which the silver drachma continued to circulate along with the Roman coinage.

4. The phrase "dollar of the middle ages" is that of R.S. Lopez (1951). Both Lopez (1951, p. 209) and Cipolla (1967, p. 15-16) cite the statement by Indicopleustes. Cipolla goes on to discuss corroborative evidence reported by earlier historians of the subject.

5. Sussman (1993) presents a sound analysis of later debasements which illustrates the general principles and raises the right questions. Rolnick et al. (1996) present some stylized observations about debasements and Velde et al. (1999) present a simple analysis that highlights the general asymmetric information that can rationalize the profitability of debasements.

6. See Spufford (1984) on the commercial revolution and the financial developments that accompanied it. On broader cultural issues - philosophical and economic thought and university life - see Gilson (1991) and Schumpeter (1954).

7. De Roover (1974, pp. 210-212) trace the development of bills of exchange to the letters of exchange and cambium contracts used a century or so before. See McCusker (1978, pp. 19-23) and Neal (1990, pp. 6-9) for discussions of the mechanics of the transaction involved in the use of bills of exchange, and Einzig (1962) for a broader historical treatment.

8. For a discussion of the mechanics of transactions involving bills of exchange see Lothian (2003).

9. These data were taken from McCusker (1978, Table 2.6, pp.46-51).

10. See Benjamin J. Cohen (1998, p.31-32) for a discussion of the links between Britain's increasing importance in international finance post- 1815 and the rise of sterling as an 
international currency.

11. France was, however, also the major force behind the conference held two years later to consider a common world money.

12. There are, however, examples that run counter to this assertion: the CFA Franc Zone in Africa and the East Caribbean Currency Area as well as a number of European countries -- in several cases city states -- like Andorra, Liechtenstein, Luxembourg, Monaco, San Marino and Vatican City that either linked their currencies to that of a larger neighbor or used the neighbors currency itself. These may, nevertheless, be the exceptions that prove the rule since all of these countries are very small and hence perhaps less not likely to vie politically with either their neighbors or with one another.

13. Barter will not occur because demand and production are structured to rule out a double coincidence of wants.

14. See, for example, Hale (1971), as well as the subsequent commentary by Hudson (1996) and VanDrunen( 2002).

15. See Chafuen (1986) for discussion of the works of the Salamancan writers and VanDrunen (2002) for a comparison of the views of Aquinas and Hayek. Aquinas'statement on the role of custom and law is particularly revealing. He writes (Summa Theologica, I-II q. 97 ):

$[\mathrm{H}]$ uman law is rightly changed, in so far as such change is conducive to the common weal. But, to a certain extent, the mere change of law is of itself prejudicial to the common good: because custom avails much for the observance of laws, seeing that what is done contrary to general custom, even in slight matters, is looked upon as grave. Consequently, when a law is changed, the binding power of the law is diminished, in so far as custom is abolished.

16. See Vaubel (2003) for a situation in which pressures of this sort could begin to mount. 